\title{
Regenerative defect in vastus lateralis muscle of patients with chronic obstructive pulmonary disease
}

\author{
Marie-Eve Thériault, Marie-Ėve Paré, Bruno B Lemire, François Maltais and Richard Debigaré*
}

\begin{abstract}
Background: Impaired skeletal muscle regeneration could contribute to the progression of muscle atrophy in patients with chronic obstructive pulmonary disease (COPD).

Methods: Satellite cells and myogenesis-related proteins were compared between healthy subjects and patients with COPD, with or without muscle atrophy. Satellite cells were isolated and cultured to assess their proliferative and differentiation aptitudes.

Results: Although satellite cell numbers in muscle samples were similar between groups, the proportion of muscle fibers with central nuclei was increased in COPD. In muscle homogenates, increased expression of MyoD and decreased expression of myogenin and MRF4 were observed in COPD. In cultured satellite cells of patients with COPD, increased protein content was observed for Pax7, Myf5 (proliferation phase) and myogenin (differentiation phase) while myosin heavy chain protein content was significantly lower during differentiation.

Conclusion: In COPD, the number of central nuclei was increased in muscle fibers suggesting a greater number of attempts to regenerate muscle tissue than in healthy subjects. Myogenesis signaling was also altered in muscle homogenates in patients with COPD and there was a profound reduction in the differentiation potential in this population as indicated by a reduced ability to incorporate myosin heavy chain into newly formed myotubes. Collectively, these results indicate that skeletal muscle regenerative capacity termination is impaired in COPD and could contribute to the progression of muscle atrophy progression in this population.
\end{abstract}

Keywords: Satellite cells, COPD, Muscle, Regeneration, Atrophy

\section{Background}

Skeletal muscle atrophy is observed in a variety of acute and chronic conditions [1-5] including chronic obstructive pulmonary disease (COPD) [6]. In COPD, this loss of muscle mass has a significant impact on quality of life [7] and is associated with premature death [8]. Many biochemical factors have been proposed to initiate and promote the development of skeletal muscle atrophy in COPD [9]. An impaired capacity for muscle regeneration has been hypothesized to take part in this process [10]. However, no studies have yet investigated whether the ability of satellite cells to proliferate and differentiate

\footnotetext{
* Correspondence: Richard.Debigare@rea.ulaval.ca

Centre de recherche Institut universitaire de cardiologie et de pneumologie de Québec, Université Laval, Québec, QC G1V 4G5, Canada
}

could be involved in the atrophying process in the context of COPD.

Skeletal muscle possesses a remarkable capacity to regenerate itself, which largely depends on muscle satellite cells and the expression of myogenic regulatory factors (MRFs). Upon activation [11-13], satellite cells proliferate into myoblasts and migrate to the requested site. In the activated state, these cells will enter the cell cycle through the expression of early MRFs such as MyoD and Myf5 [14]. Eventually, newly formed myoblasts will exit the cell cycle and differentiate into myotubes. At this stage cells will express two distinct MRFs, myogenin and MRF4. Fully differentiated myotubes will fuse to injured myofibers for repair or fuse together to form a new one [15]. To preserve an adequate population of
( Biomed Central (c) 2014 Thériault et al.; licensee BioMed Central Ltd. This is an Open Access article distributed under the terms of the Creative Commons Attribution License (http://creativecommons.org/licenses/by/2.0), which permits unrestricted use, distribution, and reproduction in any medium, provided the original work is properly credited. The Creative Commons Public Domain Dedication waiver (http://creativecommons.org/publicdomain/zero/1.0/) applies to the data made available in this article, unless otherwise stated. 
muscle satellite cells during adulthood, some newly formed myoblasts will return to a quiescent state $[16,17]$.

Transition of activated satellite cells to highly proliferative myoblasts and then to differentiated myotubes is a well regulated process. First, up-regulation of Notch signaling promotes the transition of activated satellite cells to highly proliferative myoblasts [18]. A subsequent decline in Notch signaling activity is necessary for differentiation of progenitor cells into fusion competent myoblasts [19]. Increases in the expression of Numb is known to switch off Notch signaling [18]. The transition from Notch to Wnt signaling in myogenic progenitors is a prerequisite step for differentiation [20].

Muscle is highly dynamic and muscle mass maintenance relies on the delicate balance between protein synthesis and degradation as well as the additions and loss of myonuclei. We hypothesized that the regenerative process is impaired in COPD patients presenting muscle atrophy compared to healthy individuals. This hypothesis is supported by our recent finding that satellite cell senescence is likely occurring in lower limb muscle of patients with COPD and low muscle mass [21]. To further test this hypothesis, the research protocol was divided in two distinct aims: 1) in muscle tissue, to evaluate satellite cell number, by counting the occurrence of central nuclei (a marker of newly fused satellite cells) and to study the expression pattern of myogenesisrelated proteins; and 2) in isolated and cultured satellite cells, to assess proliferation, MRFs expression and differentiation as key steps of the regeneration process. This study confirms that although limb muscle of patients with COPD and healthy age matched controls contains the same number of satellite cells, their myogenic capacities are impaired in COPD.

\section{Methods}

\section{Subjects}

Seventeen males with Global Initiative for Chronic Obstructive Lung Disease (GOLD) stage III and IV disease and nine healthy male subjects with normal lung function were consecutively recruited for this study. None of them were part of a previous study on satellite cell biology in COPD $^{21}$. COPD diagnosis was based on a past smoking history (> 10 pack-year) and pulmonary function tests showing persistent airflow obstruction (forced expiratory volume in $1 \mathrm{~s}\left[\mathrm{FEV}_{1}\right]<50 \%$ of predicted value and $\mathrm{FEV}_{1} /$ forced vital capacity $\left.[\mathrm{FVC}]<70 \%\right)$ [22]. All patients with COPD were in a stable condition at the time of the study and were neither suffering from any other diseases nor using oral corticosteroids. The institutional ethics committee (Comité d'éthique, Institut Universitaire de cardiologie et de pneumologie de Québec) approved the study protocol and each patient signed a written informed consent form.

\section{Study design}

To address aim \#1, muscle sections and homogenates of all study participants were used respectively for immunostaining and protein measurements. Eight patients with COPD and seven healthy subjects had sufficient amount of muscle tissue for isolation and culture of satellite cells and fulfilled the second aim of this study.

\section{Pulmonary function, anthropometric measurements and body composition}

Standard pulmonary function tests including spirometry, lung volumes, and carbon dioxide diffusion capacity were obtained in all subjects during the initial evaluation according to previously described guidelines [23]. Results were related to previously published normal values [24]. Height and weight were measured according to standardized methods [1]. Mid-thigh muscle cross-sectional area (MTCSA) was determined using computed tomography, as previously described [8].

\section{Muscle biopsy}

One needle biopsy of the vastus lateralis, performed as described by Bergström and routinely done in our laboratory, [25] was obtained from each participant. Muscle specimens were divided in two parts. One was frozen in liquid nitrogen and stored at $-80^{\circ} \mathrm{C}$ for analyses on immunostained muscle sections and on muscle homogenates (aim \#1)). When sufficient tissue was available, the second part of the muscle specimen (COPD $n=8$; controls $n=7$ ) was placed in a sterile plate filled with phosphate-buffered saline (PBS), covered and transported on ice under sterile cell culture hood to perform satellite cell isolation (aim \#2).

\section{Fiber typing}

Muscle sections were stained with a monoclonal antimyosin (skeletal, fast) antibody (Sigma-Aldrich, St-Louis, MO, USA) to detect type II muscle fibers using a standard immunohistochemistry protocol. The proportion of type I (nonstained), and II (darkly stained) fibers was assessed and calculated as the number of fibers of each type divided by the total number of muscle fibers on the cryosection.

\section{Satellite cells and myonuclei staining}

To assess the number of satellite cells in muscle tissue sections, immunostaining against transcription factor Pax7 (R\&D Systems) was performed. Laminin was used to delineate muscle fibers. Nuclei were labeled using DAPI. Nuclei located deep to the basal lamina and positive for Pax7 were counted as satellite cells. Satellite cells were counted in over 100 myofibers and reported as a ratio. Muscle sections $(10 \mu \mathrm{m})$ were fixed with ice-cold acetone and methanol $60 / 40(\mathrm{v} / \mathrm{v})$ at $-20^{\circ} \mathrm{C}$ for 20 minutes, washed with 
PBS, incubated with a blocking solution (horse serum 1\%) for 1 hour and then incubated with the primary antibody overnight at $4{ }^{\circ} \mathrm{C}$ in a humidified chamber. The primary antibody Pax-7 (R\&D Systems) and laminin (Dako, Glostrup, Denmark) excess was cleaned with PBS, incubated with their specific secondary antibodies, a goat anti-mouse Alexa Fluor 488 (R\&D Systems) and a goat anti-rabbit Alexa Fluor 546 (Invitrogen Corporation, Carlsbad, CA, USA) for 1 hour, washed with PBS and then incubated with DAPI for 15 minutes. Slides were analyzed and images were captured using a Nikon Eclipse E600 microscope (Nikon Corporation, Tokyo, Japan). Immunofluorescences were performed in duplicate on two different muscle cryosections.

\section{Satellite cell isolation and culture}

Satellite cells were isolated and cultured as previously published [26]. Briefly, fresh muscle samples were placed in a sterile plate filled with phosphate-buffered saline (PBS), covered and transported on ice under sterile cell culture hood. All subsequent manipulations were performed under sterile conditions. Muscle samples were minced into a slurry using a scalpel and subjected to enzymatic digestion for $1 \mathrm{~h}$ with $0,33 \%$ collagenase (Cedarlane, Hornby, ON, Canada) at $37^{\circ} \mathrm{C}$ with gentle agitation. The digested muscle specimens were then dissociated by triturating them several times and filtered through a $100 \mu \mathrm{m}$ filter (BD Biosciences, Franklin Lakes, NJ, USA). Cells were plated and grown on collagen coated dishes (SigmaAldrich) in growth medium made of Dulbecco's modified Eagle's medium (DMEM) with 1\% glucose (HyClone, Logan, UT, USA) supplemented with $20 \%$ fetal bovine serum, penicillin $50 \mathrm{U} / \mathrm{ml}$, streptomycin $50 \mu \mathrm{g} / \mathrm{ml}$ (HyClone) and $5 \mathrm{ng} / \mathrm{ml}$ bFGF (Promega, Madison, WI, USA) in a humidified $37^{\circ} \mathrm{C}, 5 \% \mathrm{CO}_{2}$ incubator. The medium was changed every two days and the cultures examined by inverted-phase microscopy. When cultured cells reached a confluence of $70 \%$ they were dissociated enzymatically with trypsin (Gibco, Carlsbad, CA, USA) and seeded for immediate propagation, or frozen into medium containing 10\% DMSO for later use. To induce differentiation into myotubes, near to confluence myoblasts were placed in differentiation medium made of DMEM with $1 \%$ glucose and supplemented with $2 \%$ horse serum (HS), penicillin $50 \mathrm{U} / \mathrm{ml}$, and streptomycin $50 \mu \mathrm{g} / \mathrm{ml}$ (HyClone). Differentiation medium was replaced every day for 7 consecutive days. Images taken from myoblasts and myotubes were captured with a Nikon 950 digital camera (Nikon Corporation). To ensure the exclusivity of the myogenic nature of the cell culture, Pax-7 (R\&D Systems, Minneapolis, NE, USA) staining was performed. Immunohistochemistry was performed using Vectastain Elite $\mathrm{ABC}$ Kit according to the instructions provided by the manufacturer (Vector Labs, Burlingame, CA, USA).

\section{Proliferation assay}

After the first passage, satellite cells were plated at a density of $5 \times 10^{4}$ cells in a $60 \mathrm{~mm}$ cultures dish. Every $24 \mathrm{~h}$, cells were trypsinized and counted using a hemacytometer during four successive days.

\section{MRFs expression}

To measure progression through myogenesis, $2 \times 10^{5}$ cells were placed in a $100 \mathrm{~mm}$ dish after their second passage. Cells were allowed 24 hours to settle and adhere before starting the experiment. Near confluent myoblasts were placed in differentiation medium for seven consecutive days. Whole cell lysates were performed every $24 \mathrm{~h}$ until complete differentiation for a total of nine days in culture. Western blotting against Pax7 (R\&D), MyoD, Myf5, Myogenin, MRF4 (Santa Cruz Biotechnology, Santa Cruz, CA, USA), and Numb (Cell Signaling Technology, Danvers, MA, USA) was performed to quantify myogenesis related protein accumulation.

\section{Differentiation assay}

To measure differentiation rate, $2 \times 10^{5}$ cells were placed in a $60 \mathrm{~mm}$ dish after their second passage. Near confluent myoblasts were placed in differentiation medium for seven consecutive days. Cell lysates were prepared every $24 \mathrm{~h}$ until seven days of differentiation. To quantify differentiation, western blotting against monoclonal antimyosin (skeletal, fast) antibody (Sigma-Aldrich) was performed.

\section{Statistical analysis}

Results are expressed as mean $( \pm$ SEM). Data from patients with COPD and healthy controls were analyzed using a one-way analysis of variance (ANOVA). Because low muscle mass is related to poor quality of life [27], reduced functional capacity [7] and survival [8], immunostaining and tissue homogenate data obtained from patients with COPD were subsequently subdivided according to a MTCSA $<70 \mathrm{~cm}^{2}$ or $>70 \mathrm{~cm}^{2}$ for further sub-analysis purposes. The $70 \mathrm{~cm}^{2}$ MTCSA threshold was used to define muscle atrophy based on a previous study showing that mortality was significantly increased in patients with MTCSA below this cutoff value [8]. Differences for all variables between patients with COPD with MTCSA $<70 \mathrm{~cm}^{2}$ and $>70 \mathrm{~cm}^{2}$ and healthy controls were analyzed using a one-way analysis of variance (ANOVA). Muscle mass was not considered in the analysis of cultured satellite cell data because the composition of the study groups was based on amount of tissue available for cell isolation and not on baseline subject 
characteristics. Differences were considered to be significant when $\mathrm{p}<0.05$.

\section{Results}

\section{Muscle homogenates}

\section{Subject's characteristics}

Anthropometric characteristics and pulmonary function data are provided in Table 1. Patients with COPD with MTCSA $>70 \mathrm{~cm}^{2}$ and healthy subjects did not significantly differ in age and body mass index. Patient with COPD and MTCSA $<70 \mathrm{~cm}^{2}$ had a significantly lower body mass index compared to the other two groups. On average, patients with COPD had moderate-to-severe airflow obstruction: eight patients had stage III COPD and nine patients had stage IV disease according to the GOLD classification [28]. Type I fiber proportion was significantly decreased in patients with COPD, while type II fiber proportion was reciprocally increased.

\section{Satellite cells and central nuclei quantification}

A representative vastus lateralis cryosection immunostained for Pax7 (expressed by satellite cells) and laminin (a major constituent of the basal lamina) is depicted in Figure 1A. The proportion of myofibers positive for Pax7 did not significantly differ between groups (Figure 1B).

A representative cryosection immunostained for nucleus and laminin is provided in Figure 2A. The number of

Table 1 Subject characteristics

\begin{tabular}{|c|c|c|c|}
\hline Characteristics & $\begin{array}{c}\text { Control } \\
(n=9)\end{array}$ & $\begin{aligned} \text { COPD } & >70 \mathrm{~cm}^{2} \\
(\mathrm{n} & =11)\end{aligned}$ & $\begin{array}{c}\text { COPD }<70 \mathrm{~cm}^{2} \\
(\mathrm{n}=6)\end{array}$ \\
\hline Age (years) & $63 \pm 2.3$ & $64 \pm 2.3$ & $70 \pm 2.4$ \\
\hline BMI $\left(\mathbf{k g} / \mathrm{m}^{2}\right)$ & $29.1 \pm 2.4$ & $28.1 \pm 2.0$ & $21.7 \pm 2.6^{b}$ \\
\hline $\mathrm{FEV}_{1}, \mathrm{~L}$ & $3.3 \pm 0.2$ & $1.0 \pm 0.2^{\mathrm{a}}$ & $0.8 \pm 0.1^{\mathrm{a}}$ \\
\hline $\mathrm{FEV}_{1}, \%$ predicted & $106.3 \pm 4.1$ & $36.0 \pm 4.9^{a}$ & $26.0 \pm 3.8^{a}$ \\
\hline $\mathrm{FEV}_{1} / \mathrm{FVC}, \%$ & $76.0 \pm 1.6$ & $36.1 \pm 1.8^{\mathrm{a}}$ & $29.0 \pm 2.6^{b}$ \\
\hline TLC, \% predicted & $98.6 \pm 6.5$ & $121.6 \pm 6.6^{a}$ & $125.7 \pm 4.8^{\mathrm{a}}$ \\
\hline RV, \% predicted & $90.1 \pm 15.3$ & $173.2 \pm 22.8^{\mathrm{a}}$ & $195.5 \pm 22.9^{\mathrm{a}}$ \\
\hline $\mathrm{DL}_{\mathrm{CO}}, \%$ predicted & $96.9 \pm 3.2$ & $57.4 \pm 6.7^{\mathrm{a}}$ & $40.0 \pm 2.8^{b}$ \\
\hline $\operatorname{MTCSA}\left(\mathrm{cm}^{2}\right)$ & $120.3 \pm 3.4$ & $86.3 \pm 4.2^{a}$ & $60.8 \pm 3.6^{b}$ \\
\hline \multicolumn{4}{|l|}{ Type / fiber } \\
\hline Distribution, \% & $51.5 \pm 5.7$ & $34.7 \pm 9.3^{\mathrm{a}}$ & $34.9 \pm 3.5^{\mathrm{a}}$ \\
\hline $\mathrm{CSA},\left(\mu \mathrm{m}^{2}\right)$ & $5170 \pm 471$ & $4711 \pm 340$ & $4883 \pm 607$ \\
\hline \multicolumn{4}{|l|}{ Type II fiber } \\
\hline Distribution, \% & $44.1 \pm 5.7$ & $65.4 \pm 9.3^{a}$ & $65.2 \pm 3.5^{a}$ \\
\hline $\mathrm{CSA},\left(\mu \mathrm{m}^{2}\right)$ & $4216 \pm 358$ & $4359 \pm 540$ & $4096 \pm 480$ \\
\hline
\end{tabular}

Values are means \pm SEM.

${ }^{a}$ statistically significant difference from control $(p<0.05)$.

${ }^{b}$ statistically significant difference from COPD $>70 \mathrm{~cm}^{2}(p<0.05)$.

Definition of abbreviations: BMI Body mass index, FEV 1 Forced expiratory

volume in 1 second, $T L C$ total lung capacity, RV Residual volume, DLCO

Diffusing capacity of carbon monoxide, MTCSA Mid-thigh cross-sectional area,

CSA Cross-sectional area. central nuclei (a marker of newly fused satellite cells) per 100 muscle fibers was significantly higher in patients with COPD and preserved muscle mass (MTCSA $>70 \mathrm{~cm}^{2}$ ) compared to patients with COPD and muscle atrophy $\left(\right.$ MTCSA $\left.<70 \mathrm{~cm}^{2}\right)$ and healthy subjects $(7.2 \pm 0.7$ vs $3.2 \pm 0.2$ vs $4.0 \pm 0.5$ respectively; $\mathrm{p}<0.0001$ ) (Figure $2 \mathrm{~B}$ ).

\section{Expression of myogenic regulatory factors}

A significant increase in MyoD protein content was observed in patients with COPD with MTCSA $<70 \mathrm{~cm}^{2}$ (Figure 3) compared to healthy subjects (2.31 foldincrease, $\mathrm{p}<0.05$ ) and to patients with COPD with MTCSA $>70 \mathrm{~cm}^{2}$ (1.31 fold-increase, $\mathrm{p}<0.05$ ). Myf5 protein content was significantly increased in both groups of patients with COPD compared to healthy subjects (1.42 and 1.49 fold-increase respectively, $\mathrm{p}<0.05)$. There was a significant decrease in myogenin (0.62 fold-decrease, $\mathrm{p}<0.005)$ and MRF4 (0.46 fold-decrease, $\mathrm{p}<0.005)$ protein contents in patients with COPD with MTCSA $>70 \mathrm{~cm}^{2}$ compared to healthy subjects. There was no difference between Pax7 and Numb (total amount) protein content between all three groups.

\section{Satellite cell analyses}

To further characterize satellite cells present in the vastus lateralis biopsies, a protocol to isolate and culture muscle satellite cells was developed. Proliferation and differentiation rates of the satellite cells were determined using this model.

\section{Subject's characteristics}

Anthropometric characteristics and pulmonary function data for subjects in whom primary muscle cell culture was performed are provided in Table 2.

\section{Isolation and characterization of satellite cells}

Cultured cells demonstrated myoblast-like and myotubeslike shapes in growing and differentiation states. Positive staining for Pax7 confirmed the satellite cell phenotype of these cells. In all cultures, at least $95 \%$ of freshly isolated muscle progenitor cells were classified as Pax7+ satellite cells by immunohistochemistry. Cells were grown under sterile conditions and no signs of any contamination were observed.

When satellite cells were isolated from the muscle samples and put into culture, a delay in their adhesion into dishes was observed. Satellite cells isolated from patients with COPD took $7.3 \pm 0.3$ days to adhere and proliferate compared to $5.5 \pm 0.3$ days $(\mathrm{p}<0.05)$ for those isolated from healthy subjects.

\section{Proliferation}

Cell proliferation was evaluated by counting growing cells every 24 hours over a 96 -hour period. The number of cells at each time point is presented in Figure 4. A 

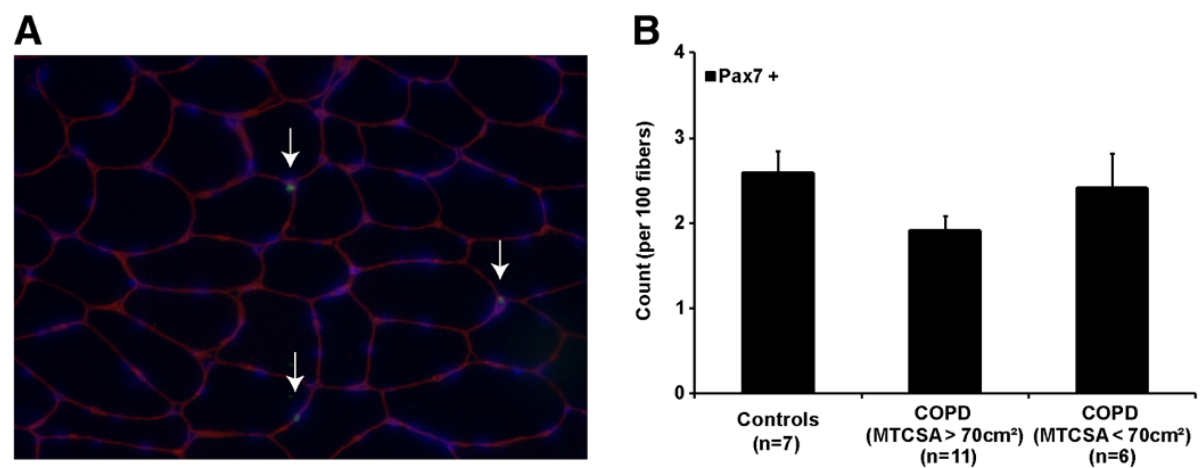

Figure 1 Satellite cell detection performed by immunostaining. (A) Vastus lateralis muscle cryosections were immunostained for co-expression and localization of nuclear Paired box transcription factor 7 (Pax7, green), DAPI (blue) and laminin (red). Labeled nuclei located deep to the basal lamina and positive for pax7 were counted as satellite cells (white arrow). (B) Labeled nuclei located deep to the basal lamina and positive for Pax7 were counted as satellite cells. The number of satellite cells is expressed over 100 fibers and reported as a ratio; ANOVA; $p>0.05$. Ratios are calculated from 9 healthy subjects, 11 COPD $\left(\right.$ MTCSA $\left.>70 \mathrm{~cm}^{2}\right)$ and 6 COPD $\left(\right.$ MTCSA $\left.<70 \mathrm{~cm}^{2}\right)$.

slight but statistically significant decrease in cell proliferation was observed at 48 hours in patients with COPD compared to healthy subjects $(\mathrm{p}<0.01)$. At 72 hour, proliferation rate in COPD was similar compared to healthy subjects with even a significant increase in proliferation at 96 hours in COPD compared to healthy individuals $(\mathrm{p}<0.005)$.

\section{Myogenesis}

Cells were grown in proliferation medium for two days than placed in differentiation medium for the remaining period of time. In COPD, there was a significant increase in Pax7 accumulation after one day in growing culture medium compared to healthy subjects (2.0 fold-increase, $\mathrm{p}<0.05$ ) (Figure $5 \mathrm{~A}$ ). MyoD protein accumulation during this period was similar between groups while significant increases in Myf5 protein accumulation $(\mathrm{p}<0.05)$ were observed in COPD compared to healthy subjects in our distinct days during differentiation (days 4 (3.2 foldincrease), 5 (3.6 fold-increase), 7 (2.9 fold-increase) and 9 (3.5 fold-increase) $(\mathrm{p}<0.05)$ ) (Figure $5 \mathrm{~B}$ and $\mathrm{C}$, respectively). Significant increases in the accumulation of myogenin in patients with COPD compared to healthy subjects were observed at days 0 (2.2 fold-increase) and 1 during proliferation (1.7 fold-increase) $(\mathrm{p}<0.05)$ (Figure 5D). The accumulation of MRF4 did not differ between groups (Figure 5E). Significant decreases in the accumulation of Numb in patients with COPD compared to healthy subjects were observed throughout the proliferation and differentiation periods (Figure $5 \mathrm{~F}$ ).

\section{Differentiation}

At the end of the myogenic process, the capacity of myoblasts to fully differentiate into myotubes was determined
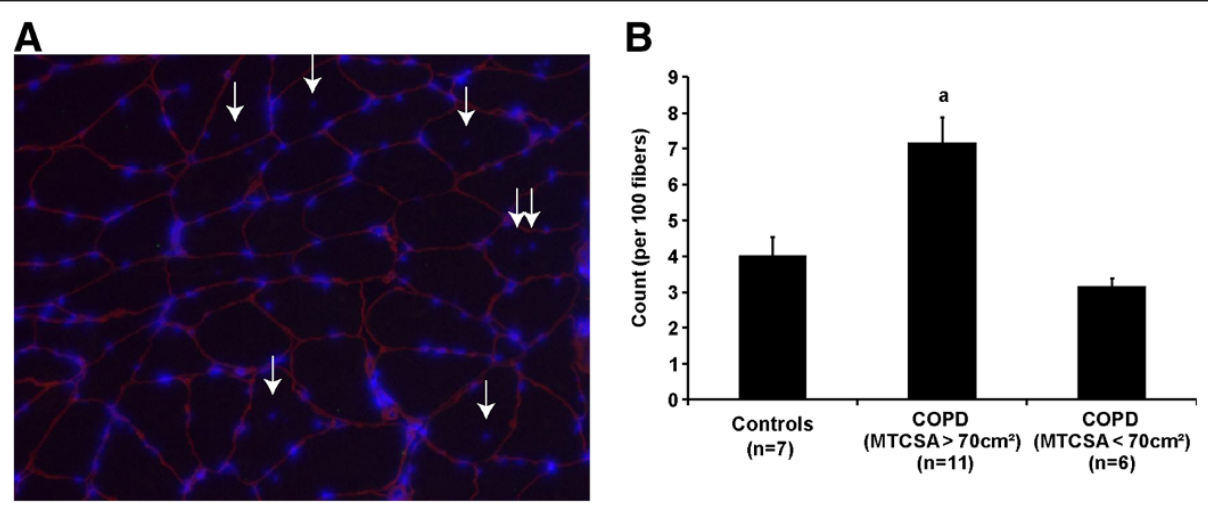

Figure 2 Central nuclei detection performed by immunostaining. (A) Cryosections were analyzed by immunostaining for nuclei (blue) and laminin (red). Immuno-detection is shown for $10 \mu \mathrm{m}$ skeletal muscle cryosections. The number of central nuclei (white arrows) is expressed over 100 fibers and reported as a ratio. Ratios are calculated from 9 healthy subjects, 11 COPD (MTCSA $\left.>70 \mathrm{~cm}^{2}\right)$ and 6 COPD (MTCSA $\left.<70 \mathrm{~cm}{ }^{2}\right)$. (B) Nucleus inside the perimeter of a given fiber delimited by laminin was counted as a central nucleus, expressed over 100 fibers and reported as a ratio. When a is present: statistically significant difference from control. When b is present b: statistically significant difference from COPD $>70 \mathrm{~cm}^{2}$ (ANOVA; $\left.p<0.05\right)$. 

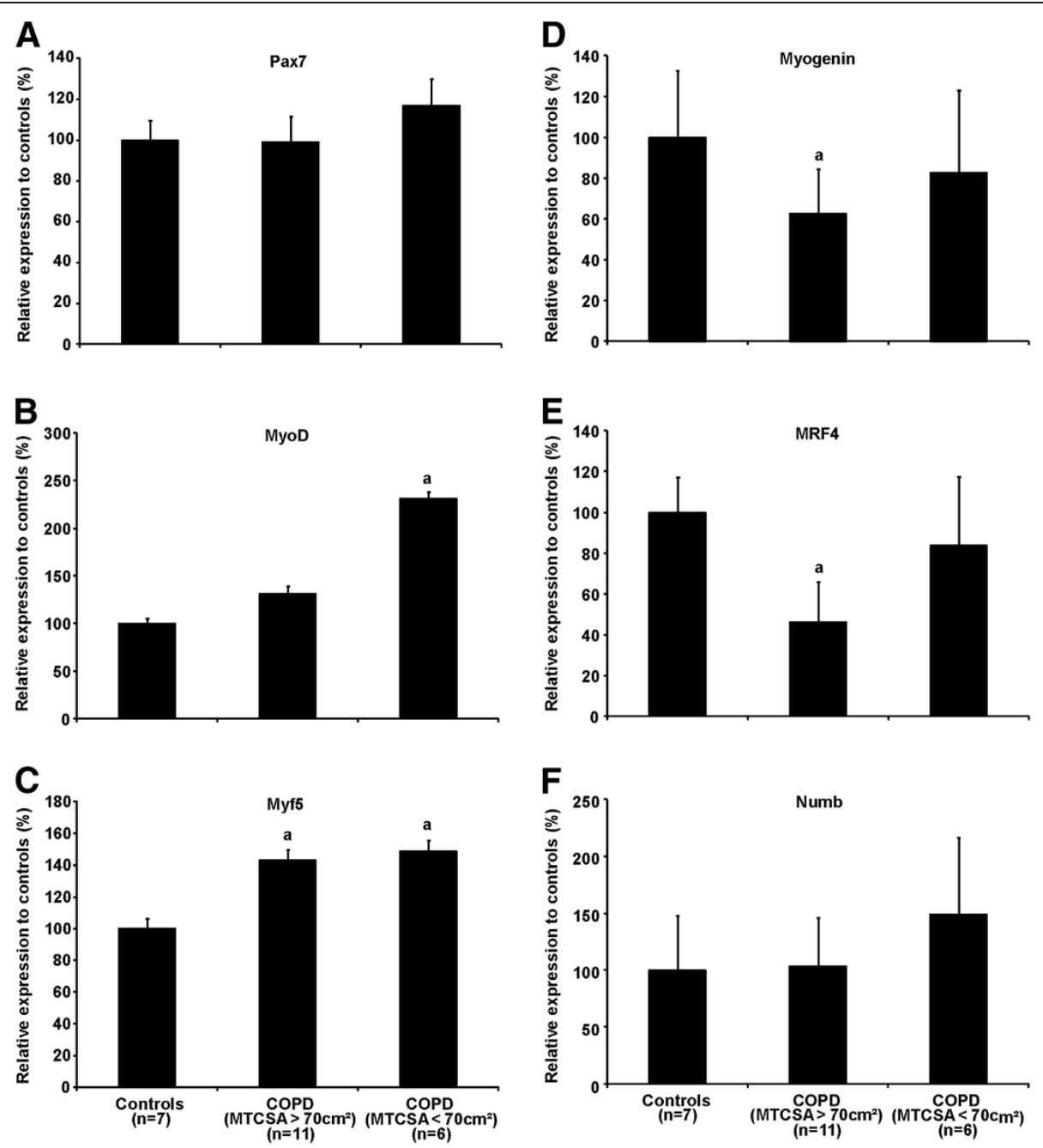

Figure 3 Western blot against Pax7 (A), MyoD (B), Myf5 (C), Myogenin (D), MRF4 (E) and Numb (F) total protein extract of the muscle biopsies obtained from the vastus lateralis. Results are reported as a percentage compared to controls subjects. When a is present: statistically significant difference from control. When $b$ is present $b$ : statistically significant difference from COPD $>70 \mathrm{~cm}^{2}$ (ANOVA; $p<0.05$ ).

by quantifying the accumulation of MHC over a period of seven days (Figure 6). After three days of differentiation, there was a profound decrease in the accumulation of MHC in COPD compared to healthy subjects that persisted throughout the rest of the differentiation period.

\section{Discussion}

One of the most striking consequences of COPD is the reduction in lower limb muscle mass resulting in loss of muscle strength $[29,30]$ which has a significant impact on exercise tolerance [31], quality of life [7] and survival [8]. In the present study we sought to determine the contribution of satellite cell activity in the development of limb muscle atrophy in patients with COPD. Our first assessments were performed directly on muscle specimens using histological characterisation and protein content measurements. Even though the number of satellite cells was similar in all groups of subjects tested, indication of increased regenerative events as evidenced by the increased number of central nuclei, was found in patients with COPD and preserved muscle mass compared to patients with COPD and low muscle mass and healthy subjects. Because satellite cells activation, proliferation and differentiation are strongly regulated by the cell environment, we developed primary cell cultures derived from muscle biopsies to further investigate satellite cells intrinsic capacity during proliferation and differentiation. It was found that satellite cells from patients with COPD have a delay in activation that was followed by a significant reduction in $\mathrm{MHC}$ accumulation at the end of the myogenic process demonstrating a defect during myotube maturation. Overall, these results are in agreement with a 
Table 2 Subjects characteristics used for primary culture

\begin{tabular}{|c|c|c|}
\hline Characteristics & Control $(n=7)$ & COPD $(n=8)$ \\
\hline Age & $63 \pm 2.3$ & $66 \pm 2.3$ \\
\hline BMI $\left(\mathrm{kg} / \mathrm{m}^{2}\right)$ & $29.1 \pm 2.4$ & $28.8 \pm 2.0$ \\
\hline $\mathrm{FEV}_{1}, \mathrm{~L}$ & $3.3 \pm 0.2$ & $1.0 \pm 0.1^{\mathrm{a}}$ \\
\hline $\mathrm{FEV}_{1}, \%$ predicted & $106.3 \pm 4.1$ & $37.0 \pm 4.0^{\mathrm{a}}$ \\
\hline $\mathrm{FEV}_{1} / \mathrm{FVC}, \%$ & $76 \pm 1.6$ & $36.5 \pm 1.1^{\mathrm{a}}$ \\
\hline TLC, \% predicted & $98.6 \pm 6.5$ & $118.0 \pm 5.5$ \\
\hline RV, \% predicted & $90.1 \pm 15.3$ & $163.5 \pm 15.9^{\mathrm{a}}$ \\
\hline $\mathrm{DL}_{\mathrm{co}}, \%$ predicted & $96.9 \pm 3.2$ & $53.3 \pm 5.8^{\mathrm{a}}$ \\
\hline $\operatorname{MTCSA}\left(\mathrm{cm}^{2}\right)$ & $120.3 \pm 3.4$ & $82.3 \pm 6.5^{a}$ \\
\hline Satellite cells (Pax $7+/ 100$ fibers) & $2.6 \pm 0.4$ & $1.7 \pm 0.3^{\mathrm{a}}$ \\
\hline Central nuclei (count/100 fibers) & $4.0 \pm 0.8$ & $6.5 \pm 1.0^{\mathrm{a}}$ \\
\hline
\end{tabular}

Values are means \pm SEM.

${ }^{\mathrm{a}}$ statistically significant difference from control $(\mathrm{p}<0.05)$.

Definition of abbreviations: BMI Body mass index, FEV 1 Forced expiratory

volume in 1 second, TLC total lung capacity, RV Residual volume,

DLCO Diffusing capacity of carbon monoxide, MTCSA Mid-thigh

cross-sectional area.

modification of satellite cells intrinsic capacities that could compromise the regenerative potential in lower limb muscles of patients with COPD.

\section{Myogenic characteristics of the vastus lateralis Satellite cell number}

In order to sustain an appropriate regenerative function and thus be able to support muscle fiber repair, satellite cell population must remain constant during lifespan. In accordance, the density of satellite cells was similar in the three groups of subjects that were investigated. We and others reported similar results in patients with COPD with or without muscle atrophy [21,32]. Together, these results

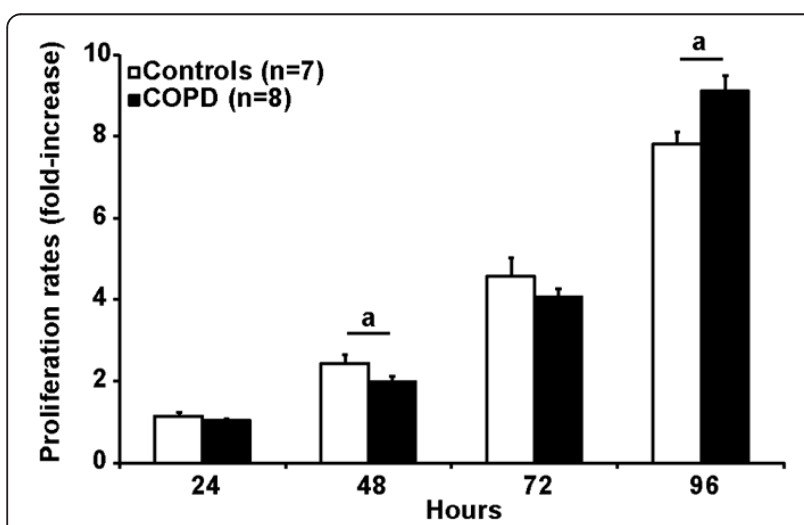

Figure 4 Proliferative potential in satellite cells isolated and cultured from healthy subjects (white bars) and patients with COPD (black bars). Following the first passage, $5 \times 10^{4}$ cells were seeded on a $60 \mathrm{~mm}$-dish and were counted every next 24 hours during 96 consecutive hours. Values are expressed as mean \pm SEM. When a is present: statistically significant difference from control (ANOVA; $p<0.05$ ). demonstrate that satellite cell number is maintained in patients with COPD and suggests that chronic lung disease does not have a significant impact on the rate of decline of the satellite cell population [32].

\section{Central nuclei and regenerative events}

Upon activation, satellite cells multiply and commit their development into myoblasts [12]. The capacity of myoblasts to differentiate into myotubes and form new myofibers is the last critical step for muscle regeneration [12]. The number of central myonuclei is an indication of committed satellite cells into the repair process $[15,33,34]$. Surprisingly we found a higher ratio of central nuclei in patients with COPD without muscle atrophy when compared to patients with COPD and muscle atrophy and healthy subjects, which suggest an increase in the number of regenerative events in this particular group. This observation demonstrates that satellite cells can be activated in this population and also supports the hypothesis that muscle tissue might be more exposed to injury during the progression of the disease [35-37]. On the other hand, in patients with a MTCSA $<70 \mathrm{~cm}^{2}$, a decrease in the occurrence of regenerative events compared to patients with COPD and preserved muscle mass is seen, confirming a previous finding by our group [21]. This observation could be interpreted as an exhaustion of the regenerative potential because of satellite cell senescence [21].

\section{MRFs protein levels}

Myogenesis is mainly controlled by four myogenic regulatory factors: MyoD, Myf5, Myogenin and MRF4 which are successively activated upon the initial transcriptional activity of Pax7 by the Notch signaling pathway [38]. MyoD is expressed in muscle satellite cells and mature myofibers [12]. We observed an upregulation of MyoD and Myf5 protein contents in whole muscle extracts from patients with COPD and muscle atrophy suggesting an attempt to accentuate proliferation. These results are in contrast to the study of Plant et al. who did not find any difference in the level of expression of MyoD in whole muscle protein lysates between patients with COPD and healthy subjects [39]. In the group of patients with COPD and preserved muscle mass, the increased expression of Myf5 (proliferation), which is paralleled by a decrease in the expression of Myogenin and MRF4 (differentiation) suggests that the switch between Notch (proliferation) and Wnt (differentiation) signaling pathway is dysfunctional leading to a sustained proliferative state, a finding that is corroborated by a previous study [40]. Furthermore, the increased number of central nuclei observed in this group is in line with the notion that satellite cells are under a sustained proliferative state. 


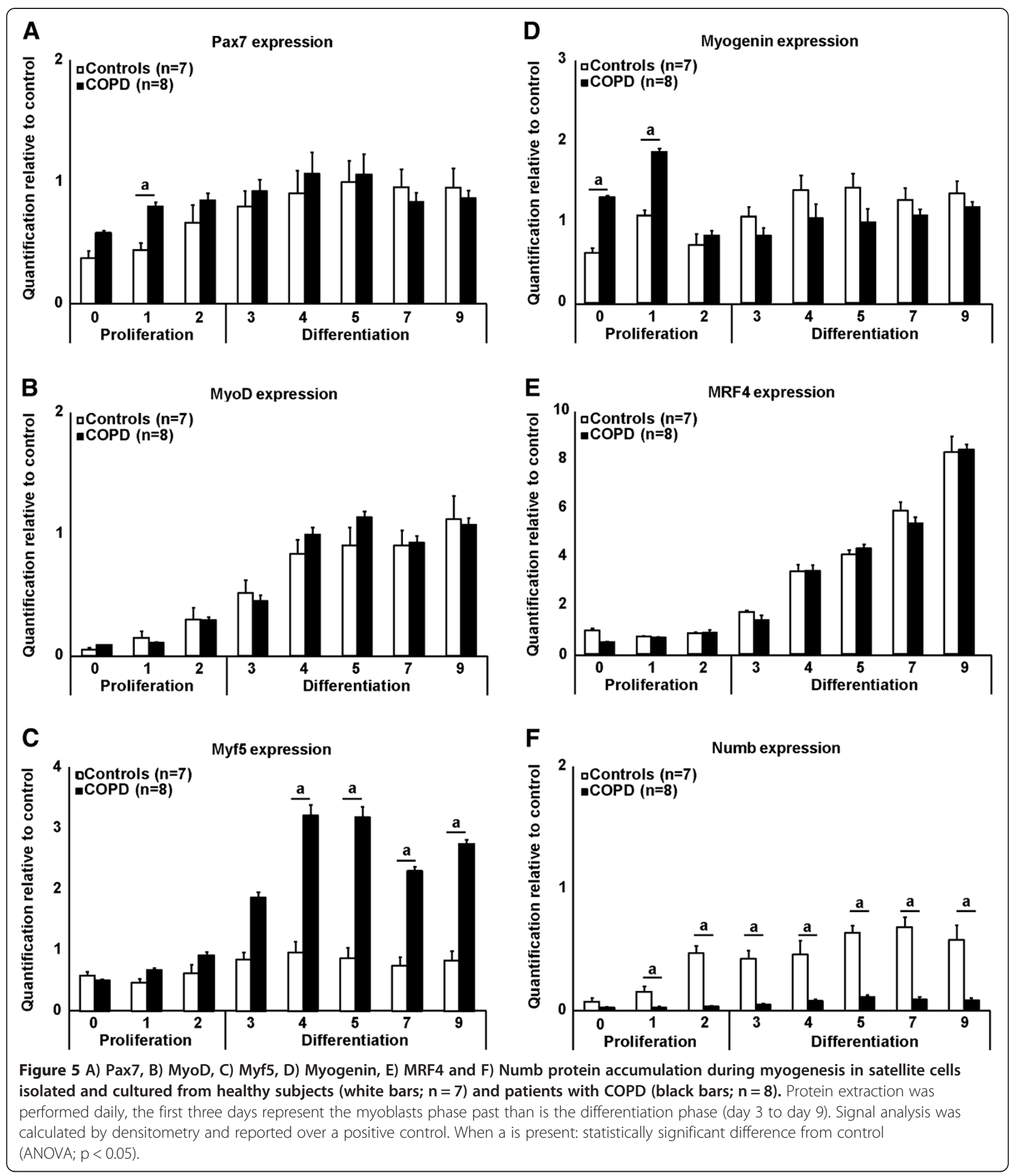

Myogenic process in satellite cells isolated from vastus lateralis

When sufficient muscle tissue was available, we successfully isolated and cultured satellite cells from patients with COPD and healthy subjects. Phenotype was confirmed by positive staining for both $\operatorname{Pax} 7$ and $\mathrm{MHC}$, two specific markers only found in muscle cells ensuring the quality of this model $[12,41]$. Moreover, isolated cells had myoblastlike and myotube-like morphologies and expressed specific MRFs during the proliferation and differentiation steps. This protocol allows the culture of satellite cells isolated from fresh human biopsies with high purity and 


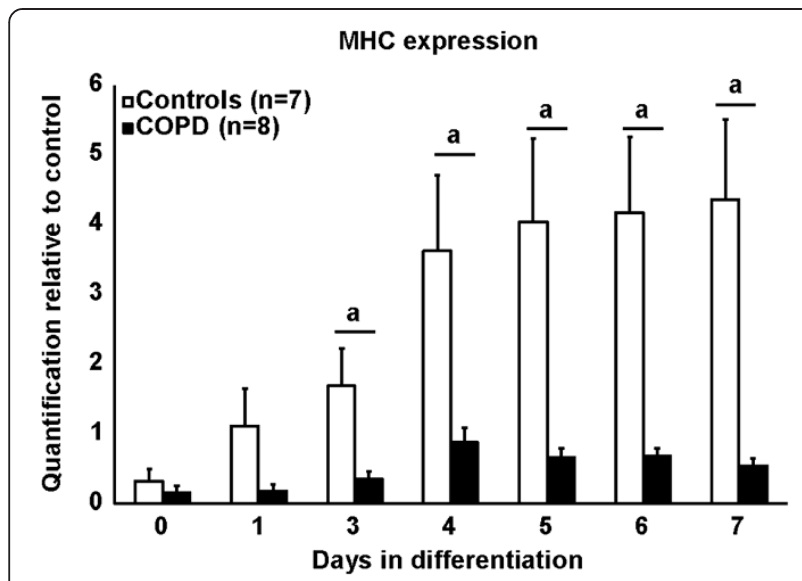

Figure 6 Skeletal myosin fast twitch protein accumulation during myogenesis in satellite cells isolated and cultured from healthy subjects (white bars; $n=9$ ) and patients with COPD (black bars; $\mathbf{n}=\mathbf{8}$ ). Protein extraction was performed daily after initial differentiation. Signal analysis was calculated by densitometry and reported over a positive control. When a is present: statistically significant difference from control (ANOVA; $\mathrm{p}<0.05$ ).

constitutes a powerful tool to assess dynamic events such as proliferation and differentiation. We found that satellite cells isolated from patients with COPD expressed a delayed activation and compromised differentiation when compared with healthy controls cells.

Interestingly, satellite cell adhesion to culture dish was delayed in patients with COPD, suggesting an impaired response to adhesion signals. Cellular proliferation is an essential event for muscle regeneration because the expansion of myogenic cells is needed to provide a sufficient number of new myonuclei for tissue repair [42]. Thus, satellite cell activation must occur within 6 hours post-injury and be followed by robust proliferation within 48 hours to induce an effective muscle regeneration [43,44]. Although unexplained, the delay in satellite cell adhesion observed in COPD supports the notion that the regenerative process could be altered in this patient population. To further characterize satellite cell activity in the context of COPD, we specifically compared the rate of proliferation of cultured cells isolated from muscle specimens and found that once activated, satellite cells from patients with COPD were able to compensate for their initial delay and produce even more myoblasts after 96 hours in culture than controls.

The proliferation of satellite cells in the context of COPD followed a distinct pattern compared to healthy subjects. Excessive oxidative stress is able to induce a delay in myoblast proliferation [45] and extensive inflammatory response alters differentiation. Because oxidative stress and low grade of systemic inflammation have been reported in COPD [46-48], this ambient milieu could promote dysfunctional proliferation pattern of satellite cells in COPD. Our conditions for cell culture were optimal and withdrawal of inflammatory and/or oxidative stress stigmas might explain the recrudescence in the proliferation rate seen after a few days in the culture dish.

\section{Expression of myogenic regulatory factors during myogenesis}

The basic-helix-loop-helix (bHLH) MRFs Myf5, MyoD, myogenin, and MRF4 act as transcriptional activators of skeletal muscle genes [49]. Myf5 and MyoD act together on a genetic pathway upstream of myogenin and MRF4 to program myogenesis in skeletal muscle cells and it has been suggested that they can counterweigh their own individual actions. For instance, mice lacking functional MyoD gene were found to express about four-fold higher levels of Myf5 leaving them without abnormalities in skeletal muscle development [50]. In our study, during the process of differentiation of satellite cells, we found a three-fold increase in Myf5 content in COPD even if MyoD accumulation was similar between both groups. This observation suggests that MyoD activity might be compromised in satellite cells growing in a distinct environment such as in COPD. Because Myf5 alone is able to support the appropriate progression of myogenesis as demonstrated by the similar expression of myogenin and MRF4 in both groups in the differentiation phase, we believe that in optimal culture conditions, satellite cells isolated from patients with COPD are able to coordinate their progression toward the formation of myoblasts.

However, the last step of differentiation appears to be affected in COPD. Indeed, the reduced MHC protein accumulation observed in satellite cells from patients with COPD is a strong evidence of an altered differentiation capacity. It can be speculated that the inability of myoblasts to fuse together, a prerequisite step to engage the late MRFs into their transcriptional activity, could explain this finding [51,52]. Altered transitional signaling in the Notch/Wnt balance is a likely explanation for this observation. The novel finding that impaired Notch signaling may be partly responsible for the loss of myogenic potential in aged muscle is intriguing, and provides a potential clue into the mechanisms underlying this altered regenerative process [34,53]. Because this study was not designed to specifically address the function of these membrane proteins, further experimentations are warranted to better characterize their role in the regenerative activity of satellite cells isolated from patients with COPD.

\section{Limitations of the study}

Because of the nature of the study design, it is difficult to determine causality between impaired regenerative 
process and muscle atrophy development in COPD. A small number of muscle specimens were used for cell isolation and culture. As a consequence, it was not possible to test the impact of muscle atrophy on satellite cell behaviour when placed into culture. In a similar way, the study was not designed to pursue mechanistic investigations. Even if these limitations are present, this innovative study brings some exciting results that provide foundation for further experimentations aimed at understanding the impact of impaired muscle regeneration on the atrophying process observed in COPD and other chronic conditions.

\section{Conclusion}

We provide strong evidence of a defect in satellite cells biology in the vastus lateralis muscle of patients with COPD. Because cultured satellite cells isolated from muscle samples obtained in patients with COPD have atypical expression pattern of MRFs that may result in poor MHC accumulation in myotubes compared to healthy subjects, we believe that muscle tissue regeneration could be impaired in COPD. The relevance of this finding for the development of muscle atrophy in this disease will need to be considered in future studies. Further efforts to delineate how the in vivo environment (growth factor availability, nature and intensity of the stressors) can affect the intrinsic capacity of satellite cells to regenerate muscle tissue will be useful.

\section{Competing interests}

The authors declare that they have no competing interests.

\section{Authors' contribution}

All authors participate in the study conception, M-E.T. perform cell culture, protein analysis, statistical analysis and draft the manuscript; M-Ė.P. help with immunostaining and ensure ethic approval; B.L. realised clinical data acquisition; F.M. perform muscle biopsies and R. D. supervise data analysis and statistical analysis. All authors read and approved the final manuscript.

\section{Acknowledgements}

The authors acknowledge the contribution of Claude H. Côté for is thoughtful comments on the manuscript and Marthe Bélanger, Marie-Josée Breton, Brigitte Jean, Josée Picard for their help in accomplishing this study.

\section{Funding}

This work has been supported by an operating grant from the Canadian Lung Association. Marie-Eve Thériault is supported by a scholarship from Réseau en Santé Respiratoire du FRSQ. F. Maltais holds a GSKVIHR Research Chair on COPD at Université Laval.

Received: 1 November 2013 Accepted: 10 March 2014 Published: 25 March 2014

\section{References}

1. Llovera M, Garcia-Martinez C, Agell N, Lopez-Soriano FJ, Authier FJ, Gherardi RK, Argiles JM: Ubiquitin and proteasome gene expression is increased in skeletal muscle of slim AIDS patients. Int J Mol Med 1998, 2:69-73.

2. Tisdale MJ: Cachexia in cancer patients. Nat Rev Cancer 2002, 2:862-871.

3. Price SR, Bailey JL, Wang X, Jurkovitz C, England BK, Ding X, Phillips LS, Mitch WE: Muscle wasting in insulinopenic rats results from activation of the ATP-dependent, ubiquitin-proteasome proteolytic pathway by a mechanism including gene transcription. J Clin Invest 1996, 98:1703-1708.
4. Brooks SV, Faulkner JA: Skeletal muscle weakness in old age: underlying mechanisms. Med Sci Sports Exerc 1994, 26:432-439.

5. Tiao G, Fagan JM, Samuels N, James JH, Hudson K, Lieberman M, Fischer JE, Hasselgren PO: Sepsis stimulates nonlysosomal, energy-dependent proteolysis and increases ubiquitin mRNA levels in rat skeletal muscle. J Clin Invest 1994, 94:2255-2264.

6. Debigare R, Marquis K, Cote CH, Tremblay RR, Michaud A, Leblanc P, Maltais F: Catabolic/anabolic balance and muscle wasting in patients with COPD. Chest 2003, 124:83-89.

7. Gosselink R, Troosters T, Decramer M: Peripheral muscle weakness contributes to exercise limitation in COPD. Am J Respir Crit Care Med 1996, 153:976-980.

8. Marquis K, Debigare R, Lacasse Y, LeBlanc P, Jobin J, Carrier G, Maltais F: Midthigh muscle cross-sectional area is a better predictor of mortality than body mass index in patients with chronic obstructive pulmonary disease. Am J Respir Crit Care Med 2002, 166:809-813.

9. Wust RC, Degens $\mathrm{H}$ : Factors contributing to muscle wasting and dysfunction in COPD patients. Int J Chron Obstruct Pulmon Dis 2007, 2:289-300.

10. Shefer G, Van de Mark DP, Richardson JB, Yablonka-Reuveni Z: Satellite-cell pool size does matter: defining the myogenic potency of aging skeletal muscle. Dev Biol 2006, 294:50-66.

11. Tidball JG: Inflammatory processes in muscle injury and repair. Am J Physiol Regul Integr Comp Physiol 2005, 288:R345-R353.

12. Charge SB, Rudnicki MA: Cellular and molecular regulation of muscle regeneration. Physiol Rev 2004, 84:209-238.

13. Hawke TJ, Garry DJ: Myogenic satellite cells: physiology to molecular biology. J Appl Physiol 2001, 91:534-551.

14. Hyatt JP, McCall GE, Kander EM, Zhong H, Roy RR, Huey KA: PAX3/7 expression coincides with MyoD during chronic skeletal muscle overload. Muscle Nerve 2008, 38:861-866.

15. Snow MH: An autoradiographic study of satellite cell differentiation into regenerating myotubes following transplantation of muscles in young rats. Cell Tissue Res 1978, 186:535-540.

16. Zammit PS, Golding JP, Nagata Y, Hudon V, Partridge TA, Beauchamp JR: Muscle satellite cells adopt divergent fates: a mechanism for self-renewal? J Cell Biol 2004, 166:347-357.

17. Collins CA, Partridge TA: Self-renewal of the adult skeletal muscle satellite cell. Cell Cycle 2005, 4:1338-1341.

18. Conboy IM, Rando TA: The regulation of Notch signaling controls satellite cell activation and cell fate determination in postnatal myogenesis. Dev Cell 2002, 3:397-409.

19. Nofziger D, Miyamoto A, Lyons KM, Weinmaster G: Notch signaling imposes two distinct blocks in the differentiation of $\mathrm{C} 2 \mathrm{C} 12$ myoblasts. Development 1999, 126:1689-1702.

20. Brack AS, Conboy IM, Conboy MJ, Shen J, Rando TA: A temporal switch from notch to Wnt signaling in muscle stem cells is necessary for normal adult myogenesis. Cell Stem Cell 2008, 2:50-59.

21. Theriault ME, Pare ME, Maltais F, Debigare R: Satellite cells senescence in limb muscle of severe patients with COPD. PLOS ONE 2012, 7:e39124.

22. From the Global Strategy for the Diagnosis, Management and Prevention of COPD: Global Initiative for Chronic Obstructive Lung Disease (GOLD); 2014. Available from: http://www.goldcopd.org/.

23. Anonymous: Standards for the diagnosis and care of patients with chronic obstructive pulmonary disease (COPD) and asthma. This official statement of the American thoracic society was adopted by the ATS board of directors, November 1986. Am Rev Respir Dis 1987, 136:225-244.

24. Quanjer PH, Tammeling GJ, Cotes JE, Pedersen OF, Peslin R, Yernault JC: Lung volumes and forced ventilatory flows. Report working party standardization of lung function tests, European community for steel and coal. Official statement of the European respiratory society. Eur Respir J Supp/ 1993, 16:5-40.

25. Doucet M, Russell AP, Leger B, Debigare R, Joanisse DR, Caron MA, LeBlanc P, Maltais F: Muscle atrophy and hypertrophy signaling in patients with chronic obstructive pulmonary disease. Am J Respir Crit Care Med 2007, 176:261-269.

26. Allen RE, Temm-Grove CJ, Sheehan SM, Rice G: Skeletal muscle satellite cell cultures. Methods Cell Biol 1997, 52:155-176.

27. Mostert R, Goris A, Weling-Scheepers C, Wouters EFM, Schols AMW: Tissue depletion and health related quality of life in patients with chronic obstructive pulmonary disease. Respir Med 2000, 94:859-867. 
28. Fabbri LM, Hurd SS: Global strategy for the diagnosis, management and prevention of COPD: 2003 update. Eur Respir J 2003, 22:1-2.

29. Debigare R, Maltais: $F$ : The major limitation to exercise performance in COPD is lower limb muscle dysfunction. J Appl Physiol 2008, 105:751-753.

30. Bernard S, LeBlanc P, Whittom F, Carrier G, Jobin J, Belleau R, Maltais F: Peripheral muscle weakness in patients with chronic obstructive pulmonary disease. Am J Respir Crit Care Med 1998, 158:629-634.

31. Saey D, Debigare R, LeBlanc P, Mador MJ, Cote CH, Jobin J, Maltais F: Contractile leg fatigue after cycle exercise: a factor limiting exercise in patients with chronic obstructive pulmonary disease. Am J Respir Crit Care Med 2003, 168:425-430.

32. Eliason G, Abdel-Halim S, Arvidsson B, Kadi F, Piehl-Aulin K: Physical performance and muscular characteristics in different stages of COPD. Scand J Med Sci Sports 2009, 19:865-870.

33. Maier A, Gambke B, Pette D: Degeneration-regeneration as a mechanism contributing to the fast to slow conversion of chronically stimulated fast-twitch rabbit muscle. Cell Tissue Res 1986, 244:635-643.

34. Conboy IM, Conboy MJ, Wagers AJ, Girma ER, Weissman IL, Rando TA: Rejuvenation of aged progenitor cells by exposure to a young systemic environment. Nature 2005, 433:760-764.

35. Moore BJ, Miller MJ, Feldman HA, Reid MB: Diaphragm atrophy and weakness in cortisone-treated rats. J Appl Physiol 1989, 67:2420-2426.

36. Reid WD, MacGowan NA: Respiratory muscle injury in animal models and humans. Mol Cell Biochem 1998, 179:63-80.

37. Orozco-Levi M: Structure and function of the respiratory muscles in patients with COPD: impairment or adaptation? Eur Respir J Supp/ 2003, 46:41s-51s.

38. Wen Y, Bi P, Liu W, Asakura A, Keller C, Kuang S: Constitutive Notch activation upregulates $\operatorname{Pax} 7$ and promotes the self-renewal of skeletal muscle satellite cells. Mol Cell Biol 2012, 32:2300-2311.

39. Plant PJ, Brooks D, Faughnan M, Bayley T, Bain J, Singer L, Correa J, Pearce D, Binnie M, Batt J: Cellular markers of muscle atrophy in chronic obstructive pulmonary disease (COPD). Am J Respir Cell Mol Biol 2010, 42:461-471.

40. Fermoselle C, Rabinovich R, Ausin P, Puig-Vilanova E, Coronell C, Sanchez F, Roca J, Gea J, Barreiro E: Does oxidative stress modulate limb muscle atrophy in severe COPD patients? Eur Respir J 2012, 40:851-862.

41. Seale P, Sabourin LA, Girgis-Gabardo A, Mansouri A, Gruss P, Rudnicki MA: Pax7 is required for the specification of myogenic satellite cells. Cell 2000, 102:777-786.

42. Le GF, Rudnicki MA: Skeletal muscle satellite cells and adult myogenesis. Curr Opin Cell Biol 2007, 19:628-633.

43. Dreyer HC, Blanco CE, Sattler FR, Schroeder ET, Wiswell RA: Satellite cell numbers in young and older men 24 hours after eccentric exercise. Muscle Nerve 2006, 33:242-253.

44. Goetsch SC, Hawke TJ, Gallardo TD, Richardson JA, Garry DJ: Transcriptional profiling and regulation of the extracellular matrix during muscle regeneration. Physiol Genomics 2003, 14:261-271.

45. Caporossi D, Ciafre SA, Pittaluga M, Savini I, Farace MG: Cellular responses to $\mathrm{H}(2) \mathrm{O}(2)$ and bleomycin-induced oxidative stress in $\mathrm{L} 6 \mathrm{C} 5$ rat myoblasts. Free Radic Biol Med 2003, 35:1355-1364.

46. Barnes PJ, Celli BR: Systemic manifestations and comorbidities of COPD. Eur Respir J 2009, 33:1165-1185.

47. Crul T, Spruit MA, Gayan-Ramirez G, Quarck R, Gosselink R, Troosters T, Pitta F, Decramer M: Markers of inflammation and disuse in vastus lateralis of chronic obstructive pulmonary disease patients. Eur J Clin Invest 2007, 37:897-904

48. Mitch WE, Price SR: Mechanisms activating proteolysis to cause muscle atrophy in catabolic conditions. J Ren Nutr 2003, 13:149-152.

49. Weintraub H, Davis R, Tapscott S, Thayer M, Krause M, Benezra R, Weintraub H, Davis R, Tapscott S, Thayer M, Krause M, Benezra R, Blackwell TK, Turner D, Rupp R, Hollenberg S: The myoD gene family: nodal point during specification of the muscle cell lineage. Science 1991, 251:761-766.

50. Rudnicki MA, Braun T, Hinuma S, Jaenisch R: Inactivation of MyoD in mice leads to up-regulation of the myogenic HLH gene Myf-5 and results in apparently normal muscle development. Cell 1992, 71:383-390.
51. Timchenko NA, lakova P, Cai ZJ, Smith JR, Timchenko LT: Molecular basis for impaired muscle differentiation in myotonic dystrophy. Mol Cell Biol 2001, 21:6927-6938.

52. Oexle K, Kohlschutter A: Cause of progression in Duchenne muscular dystrophy: impaired differentiation more probable than replicative aging. Neuropediatrics 2001, 32:123-129.

53. Carlson ME, Hsu M, Conboy IM: Imbalance between pSmad3 and Notch induces CDK inhibitors in old muscle stem cells. Nature 2008, 454:528-532.

doi:10.1186/1465-9921-15-35

Cite this article as: Thériault et al:: Regenerative defect in vastus lateralis muscle of patients with chronic obstructive pulmonary disease.

Respiratory Research 2014 15:35.

\section{Submit your next manuscript to BioMed Central and take full advantage of:}

- Convenient online submission

- Thorough peer review

- No space constraints or color figure charges

- Immediate publication on acceptance

- Inclusion in PubMed, CAS, Scopus and Google Scholar

- Research which is freely available for redistribution

Submit your manuscript at www.biomedcentral.com/submit
() Biomed Central 